\title{
HUBUNGAN ANTARA STRES DENGAN STRATEGI KOPING MAHASISWA TAHUN PERTAMA AKADEMI KEPERAWATAN
}

\section{RELATIONSHIP BETWEEN STRESS WITH COPING STRATEGY OF THE FIRST YEAR ACADEMY}

\author{
Uswatun Hasanah \\ Akper Dharma Wacana
}

\begin{abstract}
ABSTRAK
Mahasiswa merupakan individu yang sedang dalam proses menuntut ilmu dan terdaftar sedang menjalani pendidikan pada salah satu perguruan tinggi. Mahasiswa baru adalah status yang disandang mahasiswa pada tahun pertama kuliahnya. Stres yang dialami mahasiswa pada tahun pertama memberikan dampak yang negatif pada kondisi fisik dan psikis. Penelitian ini bertujuan untuk mengetahui hubungan antara stres dengan strategi koping. Desain penelitian yang digunakan adalah deskriptif korelasi. Penelitian ini menggunakan pendekatan cross sectional yaitu dilakukan pengambilan sampel dalam waktu bersamaan. Uji statistik yang digunakan adalah uji Chi Square. Hasil analisis menunjukkan bahwa dari 81 mahasiswa (69.23\%) dengan tingkat stres ringan, 77 mahasiswa (95.1\%) menggunakan strategi koping adaptif dan diantara 36 mahasiswa yang mengalami stres sedang terdapat 30 mahasiswa (8.3\%) dengan strategi koping maladaptif. Hasil penelitian menyatakan bahwa terdapat hubungan antara stres dengan strategi koping. Strategi koping yang adaptif dibutuhkan untuk dapat memodifikasi stres.
\end{abstract}

\section{Kata Kunci: Mahasiswa Tahun Pertama, Stres, Strategi Koping}

\begin{abstract}
Students are individuals who are in the process of studying and enrolled is undergoing education at one of the universities. The new student is the status the student holds during his freshman year. Stress experienced by students in the first year gives a negative impact on physical and psychological conditions. This study aims to determine the relationship between stress and coping strategies. The research design used is descriptive correlation. This study uses cross sectional approach that is done sampling at the same time. The statistical test used is Chi Square test. The result of the analysis showed that from 81 students (69.23\%) with light stress level, 77 students (95.1\%) used adaptive coping strategy and among 36 stressed students there were 30 students $(8.3 \%)$ with maladaptive coping strategy. The results suggest that there is a relationship between stress and coping strategies. Adaptive coping strategies are needed to be able to modify stress.
\end{abstract}

Keywords: First Year Students, Stress, Coping Strategy 


\section{PENDAHULUAN}

Mahasiswa merupakan individu yang sedang dalam proses menuntut ilmu dan terdaftar sedang menjalani pendidikan pada salah satu perguruan tinggi. ${ }^{1}$ Mahasiswa tahun pertama juga mengalami peralihan dari remaja ke dewasa. Masa remaja dimulai sekitar usia 10 hingga 13 tahun yang berakhir pada usia 18 hingga 22 tahun. ${ }^{2}$ Peralihan tersebut seringkali mengakibatkan perubahan dan stres bagi mahasiswa tahun pertama karena dihadapkan dengan lingkungan baru dan tidak sedikit mahasiswa tahun pertama kelimpungan untuk mengatasi masalah dan konflik yang dialami. ${ }^{3}$

Mahasiswa tahun pertama memiliki tingkat stres lebih tinggi apabila dibandingkan dengan mahasiswa lain karena mahasiswa tahun pertama akan dihadapkan dengan kejadian menekan seperti konflik hubungan dengan orang tua, pacar, dan teman serta prestasi akademik rendah dan masalah keuangan. Selain itu, mahasiswa tahun pertama harus menyesuaikan diri dengan lingkungan sosial yang baru. ${ }^{4}$

Stres merupakan kondisi yang disebabkan oleh interaksi antara seseorang dengan lingkungan yang bersumber pada sistem biologis, psikologis, dan sosial dari seseorang. ${ }^{5}$ Sedangkan stres merupakan keseluruhan proses yang meliputi stimulasi, kejadian, peristiwa, dan respon interpretasi seseorang yang menimbulkan ketegangan di luar kemampuan seseorang untuk mengatasi. ${ }^{6}$

Hasil penelitian pada mahasiswa Tingkat Persiapan Bersama Tahun Akademik 2005/2006 yang tinggal di asrama putra dan asrama putri kampus IPB Darmaga menunjukkan bahwa $62,7 \%$ mahasiswa mengalami stres tingkat tinggi, 32,7 \% mahasiswa mengalami stres tingkat sedang, dan 4,7\% mahasiswa mengalami stres tingkat ringan. ${ }^{7}$ Sedangkan hasil penelitian Silalahi (2010) pada mahasiswa tahun pertama Fakultas Kedokteran Perguruan tinggi Sumatera Utara menunjukkan bahwa $8 \%$ mahasiswa mengalami stres tingkat tinggi, 46 $\%$ mahasiswa mengalami stres tingkat sedang, dan $46 \%$ mahasiswa mengalami stres tingkat rendah. ${ }^{8}$ Selain itu, penelitian yang dilakukan oleh Abdulghani di Arab Saudi, yang dikutip dalam penelitian Lisa (2012) menyatakan bahwa prevalensi stres tertinggi dialami oleh mahasiswa Fakultas Kedokteran tahun pertama yaitu $74,2 \%$ dan pada tahun berikutnya prevalensinya menurun. $^{9}$

Stres yang dialami mahasiswa memberikan dampak yang negatif pada kondisi fisik dan psikis seseorang. Dampak tersebut dapat berupa gejala fisiologis, emosional, kognitif, hubungan interpersonal dan organisasional. ${ }^{10}$ Selain itu, dampak stres yang dapat dialami mahasiswa seringkali berupa tingkah laku yang negatif seperti 
merokok, minum minuman keras, pengambilan sampel dalam waktu mengkonsumsi junk food, bahkan sampai bunuh diri.

Berbagai dampak stres tersebut dapat mengganggu mahasiswa dalam menjalani proses studinya sehingga membutuhkan mekanisme koping yang tepat. Untuk dapat memodifikasi stres dibutuhkan mekanisme koping yang adaptif. Mekanisme koping adalah suatu mekanisme yang dapat memodifikasi stres sehingga kemungkinan proses adaptasi dapat dipermudah. Pendekatan individu dalam menanggulangi stres yaitu koping berfokus pada emosi dan koping berfokus pada masalah. ${ }^{11}$ Stres yang dialami mahasiswa dapat mempengaruhi strategi koping yang dilakukan mahasiswa.

\section{METODE}

Desain penelitian yang digunakan adalah deskriptif korelasi. Desain ini dipilih untuk menjelaskan hubungan antara stres dengan strategi koping mahasiswa tahun pertama Akademi Keperawatan Dharma Wacana. Tujuan penelitian dengan menggunakan metode ini adalah untuk memperoleh gambaran fenomena yang terjadi dalam suatu populasi tertentu. Variabel independen dalam penelitian ini adalah stres sedangkan variabel dependen yaitu strategi koping. Penelitian ini menggunakan pendekatan cross sectional yaitu dilakukan bersamaan. $^{12}$

Penelitian ini menggunakan alat ukur berupa kuesioner yang diadopsi dan dimodifikasi dari kuesioner Perceived Stres Scale (PSS) dan Coping Behavior Inventory (CBI) oleh Lin (2006). ${ }^{13}$ Kuesioner Perceived Stres Scale (PSS) terdiri dari 24 item pertanyaan yang berisi tentang stres yang dialami mahasiswa tahun pertama serta 17 pertanyaan yang dimodifikasi dari Coping Behavior Inventory (CBI). Peneliti memodifikasi kuesioner dengan menyesuaikan karakteristik responden dan sesuai dengan tujuan penelitian. Kuesioner yang digunakan dalam penelitian ini menggunakan skala Likert yang dirancang oleh peneliti berdasarkan studi pustaka. Analisis bivariat menggunakan uji chi-square.

\section{HASIL}

Usia mahasiswa tahun pertama berada pada rentang 17-22 tahun dengan usia terbanyak yaitu 71 mahasiswa (60.68\%) berusia 18 tahun, dengan mayoritas berjenis kelamin perempuan. sebanyak 49 orang (41.88\%) merupakan anak sulung dan mahasiswa memiliki motivasi yang kuat untuk menjadi perawat yaitu berjumlah 68 orang $(58.12 \%)$.

Tabel dibawah ini menunjukkan distribusi tingkat stres mahasiswa tahun pertama. 
Tabel 1.

Distribusi frekuensi mahasiswa tahun pertama berdasarkan Tingkat Stres di Akper Dharma Wacana Metro $(n=117)$

\begin{tabular}{lcc}
\hline Tingkat stres & $\begin{array}{c}\text { Frekuensi } \\
(\mathbf{n})\end{array}$ & $\begin{array}{c}\text { Persentase } \\
(\boldsymbol{\%})\end{array}$ \\
\hline Ringan & 81 & 69.23 \\
Sedang & 36 & 30.77 \\
Berat & 0 & 0 \\
\hline
\end{tabular}

Tingkat stres yang dialami mahasiswa tahun pertama mayoritas pada tingkat ringan sebanyak 81 mahasiswa (69.23\%). Tidak terdapat mahasiswa dengan stres berat.

\section{Tabel 2.}

Distribusi frekuensi mahasiswa tahun pertama berdasarkan Strategi Koping di Akper Dharma Wacana Metro $(n=117)$

\begin{tabular}{lcc}
\hline $\begin{array}{l}\text { Strategi } \\
\text { Koping }\end{array}$ & Frekuensi (n) & $\begin{array}{c}\text { Persentase } \\
(\boldsymbol{\%})\end{array}$ \\
\hline Adaptif & 83 & 70.94 \\
Maladaptif & 34 & 29.06 \\
\hline
\end{tabular}

Strategi koping yang dominan dipilih mahasiswa tahun pertama yaitu adaptif sejumlah 83 mahasiswa (70.94\%).

Tabel 3.

Hubungan Tingkat Stres dengan Strategi Koping $(n=117)$

\begin{tabular}{|c|c|c|c|c|c|c|c|}
\hline \multirow{3}{*}{$\begin{array}{c}\text { Tingkat } \\
\text { stres }\end{array}$} & \multicolumn{4}{|c|}{ Strategi koping } & \multirow{2}{*}{\multicolumn{2}{|c|}{ Total }} & \multirow{2}{*}{$\begin{array}{c}p \\
\text { value } \\
\left(\mathbf{X}^{2}\right)\end{array}$} \\
\hline & \multicolumn{2}{|c|}{ Adaptif } & \multicolumn{2}{|c|}{$\begin{array}{c}\text { Maladap } \\
\text { tif }\end{array}$} & & & \\
\hline & $\mathbf{n}$ & $\%$ & $\mathbf{N}$ & $\%$ & $\mathbf{N}$ & $\%$ & 0.009 \\
\hline Ringan & 77 & 95.1 & 4 & 4.9 & 81 & 100 & \\
\hline Sedang & 6 & 16.7 & 30 & 8.3 & 36 & 100 & \\
\hline Berat & 0 & 0 & 0 & 0 & 0 & 0 & \\
\hline Total & 83 & 70.9 & 34 & 29.1 & 117 & 100 & \\
\hline
\end{tabular}

Hasil analisis menunjukkan bahwa dari 81 mahasiswa $(69.23 \%)$ dengan tingkat stres ringan, 77 mahasiswa (95.1\%) menggunakan strategi koping adaptif dan 4 mahasiswa (4.9\%) menggunakan strategi koping maladaptif. Diantara 36 mahasiswa yang mengalami stres sedang terdapat 6 mahasiswa (16.7\%) dengan strategi koping adaptif dan 30 mahasiswa $(8.3 \%)$ dengan strategi koping maladaptif. Berdasarkan hasil uji statistik didapatkan $p$ value $=0.009$, artinya $p$ value < 0.05. dengan demikian terdapat hubungan antara stres dengan strategi koping mahasiswa atau $\mathrm{H}_{0}$ ditolak.

\section{PEMBAHASAN}

Hasil penelitian menunjukkan adanya hubungan antara stres dengan strategi koping mahasiswa tahun pertama.

Stres adalah suatu reaksi tubuh yang dipaksa yang menganggu equilibrium (homeostasis) fisiologi normal. ${ }^{14}$ Stres adalah reaksi/respons tubuh terhadap stresor psikososial (tekanan mental/beban kehidupan). Stres dewasa ini digunakan secara bergantian untuk menjelaskan berbagai stimulus dengan intensitas berlebihan yang tidak disukai berupa respons fisiologis, perilaku, dan subjektif terhadap stres; konteks yang menjembatani pertemuan antara individu dengan stimulus yang membuat stres; semua sebagai suatu sistem. ${ }^{15}$

Secara fisiologi, situasi stres mengaktivasi hipotalamus yang selanjutnya mengendalikan dua sistem neuroendokrin, 
yaitu sistem simpatis dan sistem korteks adrenal. Sistem saraf simpatik berespons terhadap impuls saraf dari hipotalamus yaitu dengan mengaktivasi berbagai organ dan otot polos yang berada di bawah pengendaliannya, sebagai contohnya, ia meningkatkan kecepatan denyut jantung dan mendilatasi pupil. Sistem saraf simpatis juga memberi sinyal ke medula adrenal untuk melepaskan epinefrin dan norepinefrin ke aliran darah. Sistem korteks adrenal diaktivasi jika hipotalamus mensekresikan CRF, suatu zat kimia yang bekerja pada kelenjar hipofisis yang terletak tepat di bawah hipotalamus. Kelenjar hipofisis selanjutnya mensekresikan hormon ACTH, yang dibawa melalui aliran darah ke korteks adrenal. Dimana, ia menstimulasi pelepasan sekelompok hormon, termasuk kortisol, yang meregulasi kadar gula darah. ACTH juga memberi sinyal ke kelenjar endokrin lain untuk melepaskan sekitar 30 hormon. Efek kombinasi berbagai hormon stres yang dibawa melalui aliran darah ditambah aktivitas neural cabang simpatik dari sistem saraf otonomik berperan dalam respons fight or flight. ${ }^{16}$

Stressor yang biasa dihadapi oleh mahasiswa keperawatan adalah kesulitan dalam menyeimbangkan kebutuhan rumah dan kuliah, tekanan waktu, keuangan, jarak yang terbentuk antara mahasiswa dengan staf pengajar, ketidaksiapan dalam menghadapi perkuliahan, perasaan tidak memliki keahlian yang memadai. ${ }^{17}$ Sumber stres mahasiswa yang lain menurut Pryjmachuk dan Richards (2007, dalam Martos, Landa, \& Zafra, 2011) yaitu masalah akademik (ujian dan evaluasi, ketakukan atau kegagalan saat pelatihan, beban tugas yang terlalu berat), masalah di area klinik (takut akan membuat masalah, respon negatif terhadap kematian dan penderitaan yang dialami pasien, hubungan dengan berbagai profesi lain) dan masalah pribadi atau sosial (masalah ekonomi, ketidakseimbangan antara tugas sebagai anggota keluarga dan sebagai mahasiswa). ${ }^{18}$

Stres sedang dan stres berat dapat memicu terjadinya penyakit. Stres sedang terjadi lebih lama, dari beberapa jam hingga beberapa hari. Contoh dari stresor yang dapat menimbulkan stres sedang adalah kesepakatan yang belum selesai, beban kerja yang berlebihan, mengharapkan pekerjaan baru, dan anggota keluarga yang pergi dalam waktu yang lama. Stres berat adalah stres kronis yang terjadi beberapa minggu sampai beberapa tahun. Contoh dari stresor yang dapat menimbulkan stres berat adalah hubungan suami istri yang tidak harmonis, kesulitan finansial, dan penyakit fisik yang lama.

Perubahan eksternal dan internal yang dialami remaja yang menjadi mahasiswa memerlukan penyesuaian diri yang tepat. Mahasiswa tahun pertama yang tidak berhasil beradaptasi dengan lingkungan baru tersebut dapat mengalami berbagai masalah, termasuk masalah dalam membina hubungan dengan 
orang lain. Berdasarkan penelitian terhadap 607 mahasiswa tahun pertama Perguruan tinggi Latvia didapat hasil bahwa 52,6 persen mahasiswa mengalami kesulitan dalam membentuk hubungan baru. Metode penyesuaian diri yang dilakukan mahasiswa tahun pertama dapat dilakukan melalui interaksi yang didalamnya juga melibatkan komunikasi. $^{19}$

Penyesuaian diri sangat diperlukan oleh mahasiswa tahun pertama, akan tetapi pada masa sekarang pengungkapan diri pada mahasiswa menghadapi tantangan yang cukup berat karena pengaruh gaya hidup mahasiswa dan perkembangan teknologi yang semakin mempersempit peran orang lain dalam kehidupan sehari-hari. Kenyataannya sekarang banyak mahasiswa yang mengalami individualisasi

atau lebih senang melakukan segala sesuatu sendirian dan mulai mengabaikan peran orangorang di sekitarnya. $^{20}$ Sikap egois mengakibatkan mahasiswa merasa asing dengan lingkungannya sehingga enggan untuk terlibat dalam pembicaraan yang mendalam dengan orang lain.

Stres akan dialami dalam berbagai keadaan seperti rasa kesepian, kurang tidur, gelisah, kebingungan. ${ }^{21}$ Oleh karena itu, stres dapat menyebabkan kehidupan dan pergaulan sehari-hari seorang mahasiswa terganggu sehingga memberi dampak negatif terhadap kesehatan, interaksi sosial dan pencapaian akademik mereka. Apabila stres dilihat dari aspek negatif atau tekanan yang terlalu tinggi, maka dapat menyebabkan dampak negatif terhadap kesehatan dan pencapaian akademik seseorang mahasiswa. ${ }^{22}$

Tubuh perlu melakukan penyesuaian terhadap stresor. Jika tubuh tidak mampu menyesuaikan diri dengan perubahan lingkungan, maka dapat mengakibatkan gangguan keseimbangan tubuh, sama halnya dengan rasa sakit kepala yang dialami oleh mahasiswa. ${ }^{23}$ Sehingga tingkat stres akademik pada mahasiswa termasuk sumber-sumber stres akademik perlu mendapat perhatian untuk meminimalisir dampak negatif dari stres karena semakin meningkat stres yang dialami mahasiswa secara bertahap, maka akan menurunkan energi dan respon adaptif.

Mahasiswa keperawatan membutuhkan koping yang tepat untuk mengatasi stres yang dialami saat mengikuti praktik klinik sehingga mereka dapat menyelesaikan masalah, menyesuaikan diri dengan perubahan lingkungan belajar yang dihadapi dan dapat memberikan respon yang sesuai terhadap kondisi stres itu sendiri. Strategi koping yang tepat sangat dibutuhkan untuk mengurangi atau menghindari dampak dari kondisi stres yang tidak diinginkan. Penelitian ini menyajikan hasil bahwa responden lebih memilih menggunakan strategi koping menyelesaikan masalah dalam mengatasi stres yang mereka rasakan. Koping merupakan cara yang dilakukan individu dalam menyelesaikan masalah, menyesuaikan keinginan yang akan dicapai, dan respon terhadap situasi yang menjadi ancaman bagi diri indvidu. ${ }^{24}$ 
Dapat dilihat bahwa dalam penelitian ini mahasiswa mencoba untuk mencari jenis strategi koping yang tepat dan efektif menurut mahasiswa tersebut dalam menangani stres yang mereka alami. Dua model strategi koping yang ternyata digunakan oleh mahasiswa yang menjadi responden dalam penelitian ini, yaitu problemfocused coping dan emotion-focused coping. Dapat dilihat adanya mahasiswa yang berusaha untuk menyelesaikan masalah yang dihadapi untuk menangani stres yang mereka muncul, namun tidak sedikit juga mahasiswa melibatkan emosi dalam menghadapai stres dilahan pratik yaitu dengan menghindari sumber stres tersebut. ${ }^{24}$

\section{KESIMPULAN}

Responden dalam penelitian ini usianya berada pada rentang 17-22 tahun dengan usia terbanyak yaitu 71 mahasiswa $(60.68 \%)$ berusia 18 tahun, dengan mayoritas berjenis kelamin perempuan. sebanyak 49 orang $(41.88 \%)$ merupakan anak sulung dan mahasiswa memiliki motivasi yang kuat untuk menjadi perawat yaitu berjumlah 68 orang $(58.12 \%)$. Dari hasil penelitian didapatkan bahwa terdapat hubungan antara stres dengan strategi koping pada mahasiswa tahun pertama Akper Dharma Wacana Metro.

\section{DAFTAR PUSTAKA}

1. Hartaji, Damar A. (2012). Motivasi Berprestasi Pada Mahasiswa yang Berkuliah Dengan Jurusan Pilihan Orangtua. Fakultas Psikologi Universitas Gunadarma. (tidak diterbitkan)
2. Santrock, John W. (2007). Adolescence Perkembangan Remaja. Jakarta: Erlangga.

3. Papalia, Diane \& Feldman, RD. (2009). Human Development. Jakarta: Kencana.

4. Greenberg, Jerrold S. (2004). Comprehensive Stress Management. New York :

5. Mc.Graw-Hill.Sarafino, E. P., \& Smith, T. W. (2011). Health psychology : Biopsychosocial interactions (7th ed.). United States of America : John Willey \& Sons Inc.

6. Safaria, T., dan Rahardi, R.K. (2004). Menjadi Pribadi Berprestasi: Strategi Kerasan Kerja di Kantor. Yogyakarta: Grasindo.

7. Hernawati. (2006). Tingkat Stres dan Strategi Koping Menghadapi Stres pada Mahasiswa Tingkat Persiapan Bersama Tahun Akademik 2005/2006.J.Il.Pert.Indon 2006.Vol. 11(2) $: 43$.

8. Silalahi, Novrita. (2010). Gambaran Stres pada Mahasiswa Tahun Pertama Fakultas Kedokteran Universitas Sumatera Utara. Medan:FK USU.

9. Agustina, Lisa (2012) Pengaruh motivasi belajar siswa terhadap hasil belajar IPA Siswa Kelas IV di SDN Taruma Negara Kecamatan Tawang Kota Tasikmalaya. Jurnal Pendidikan Dasar Vol. 11 No. 1 April 2012.

10. Rice, Philip.L. (1992). Stress \& Health Principles and Practice for Coping and Wellness. California: Pasific Grove.

11. Abraham dan shanley. (1997). Psikologi Sosial untuk Perawat. Jakarta : EGC

12. Sugiyono. (2005). Memahami Penelitian Kualitatif. Bandung: Penerbit Alfabeta.

13. Rasmund. (2004). Pengertian Stres, Sumber Stres, dan Sifat Stresor. Dalam: Stres,Koping, dan Adaptasi Edisi ke-1. Jakarta: Sagung Seto,

14. Julie K.Stegman. (2005). Stedman's Medical Dictionary. Fourth edition. United States, America: Lippincott William \& Wilkins.

15. WHO. (2003). Adolescence Mental Health Promotion. New Delhi : South East Asia 
Regional Office of the World Health Organization

16. Nasution, I.K. (2007). Stres pada Remaja. Universitas Sumatera Utara. Diunduh dari:http://repository.usu.ac.id/bitstream/1 23456789/3637/1/132316815\%281\%29.p df [Diakses pada 4 Maret 2010].

17. Gunarsa, Singgih \& Gunarsa, Yulia. (2001). Psikologi Praktis Anak, Remaja dan Keluarga. Jakarta: Gunung Mulia.

18. Landa, A. J. M., Martos, P. M., \& Zafra, L. E. (2010). Does perceived emotional intelligence and optimism/pessimism predict psychological well-being?.Journal Happiness Study.

19. Voitkane, S. (2001). First Year Students' Social Adjustment to University.http://www.ispaweb.org/en/coll oquium/nyborg\%20Presentation/voitkane. htm. Down Loaded pada 5 Juni 2005.

20. Majida, R. (1999) . Mahasiswa Sosok Apatis? Kompas Mahasiswa. No. 63. h. 27-28.

21. Kimberly, A. S. (2012). Understanding the link between social and emotional wellbeing and peer relations in early adolescence: Gender-Specific Predictors of Peer Acceptance. Journal Youth Adolescence, 39, 1330-1342

22. Mastura M, Fadilah Z, Nor Akmar N, (2007). Analisis faktor penyebab stres dikalangan pelajar. Jurnal Kemanusiaan bil.9.

23. Smeltzer \& Bare . (2008). Textbook of Medical Surgical Nursing Vol.2. Philadelphia: Linppincott William \& Wilkins.

24. Keliat, B.A. (2005). Proses kesehatan jiwa. Edisi 1. Jakarta : EGC.

25. Sarafino, E. P. (2006). Health Psychology : Biopsychosocial Interactions. Fifth Edition. USA: John Wiley \& Sons. 